\title{
CATATAN SINGKAT TENTANG ALAT-ALAT TULANG NGANDONG
}

\section{Truman Simanjuntak}

\section{PENDAHULUAN}

\section{I}

Pengertian alat tulang dalam tulisan ini meliputi alat-alat yang terbuat dari tulang dan tanduk binatang serta alat dari duri ikan. Alat tulang merupakan salah satu jenis hasil teknologi manusia purba yang dipergunakan sebagai sarana untuk memenuhi kebutuhannya. Alat jenis ini sudah dikenal sejak adanya permulaan kegiatan manusia yang pada mulanya berlatar belakang pada perburuan binatang sebagai salah satu sumber makanan. Dalam hal ini tulang-tulang binatang hasil buruan dipecahkan untuk mendapatkan sumsumnya dan pecahanpecahan yang baik dipilih untuk dijadikan alat atau setidak-tidaknya untuk dijadikan alat secara insidentil (Kenneth P. Oakley 1976: 14).

Baik di Indonesia maupun di luar Indonesia (terutama di Eropah) kebudayaan alat-flat tulang pernah mengalami perkembangan yang pesat. Kebudayaan alat tulang di Eropah menonjol pada tingkat "'Magdalenian", yaitu suatu tingkat budaya Paleolitik akhir di Eropah (istilah Magdalenian berasal dari La Madeleine yaitu nama sebuah gua di Dordogne, Perancis. Masyarakat Magdalenian hidup dalam gua-gua dengan kegiatan berburu rusa dan binatang-binatang besar lainnya pada jaman Es terakhir. Mereka telah membuat alat-alat tulang dan tanduk serta suatu seni pahat dan lukisan gua yang tinggi (The Encyclopedia Americana $18,1978: 114)$.

Kebudayaan alat-alat tulang di Indonesia dikenal dengan adanya penemuan-penemuan dari Ngandong, yaitu sebuah dukuh di tepi Bengawan Solo dalam wilayah Kel. Kalikangkung, Kec. Menden, Kabupaten Blora, Jawa Tengah. Dari hasil-hasil penelitian yang dilakukan sejak jaman penjajahan Belanda hingga masa sekarang berbagai peninggalan penting ditemukan di situs ini. Peninggalan-peninggalan tersebut adalah berupa sisa-sisa Pithecanthropus Soloensis yang hingga kini telah mencapai 16 individu (T. Jacob 1978a; 18; 1979b: 31; R.P. Soejono dkk., 1975: 64-65), sisa-sisa binatang purba serta sisa-sisa artefaktual seperti alat-alat serpih dan bola-bola batu di samping alatalat tulang (Truman Simanjuntak 1980).

\section{II}

\section{ALAT-ALAT TULANG NGANDONG}

\section{A. Hasil Penelitian Terdahulu}

Penelitian-penelitian yang dilaksanakan terdahulu (masa penjajahan Belanda) berhasil menemukan sejumlah alat-alat tulang dari Ngandong dan sekitarnya. Temuan dari Ngandong adalah berupa: 
1. Sejumlah fragmen-fragmen tanduk rusa: salah satu di antaranya dipotong miring dan cabang lainnya dipotong kasar. Cabang-cabang lainnya mempunyai ujung-ujung yang tajam;

2. Sebuah duri ikan pari ditemukan dalam endapan yang sama dengan fragmen-fragmen tanduk rusa di atas. Duri ikan ini diperkirakan sebagai mata tombak.

Alat-alat tersebut di atas ditemukan dalam konteks penemuan Pithecanthropus Soloensis bersama-sama dengan alat-alat serpih dan bolabola batu (H.R. Van Heekeren 1972: 58; R.P. Soejono dkk., 1975: 106).

Temuan-temuan lain berasal dari Sidorejo dekat Watualang, sekitar 9 km di sebelah selatan Ngandong, yaitu berupa:

1. Sebuah matatombak dari tulang yang kedua sisinya dibuat bergerigi;

2. Sebuah "chopper" dari tanduk rusa;

3. Sebuah mata tombak dari duri ikan.

Mata tombak bergerigi tersebut di atas ditemukan di atas lapisan tempat penemuan fosil-fosil. Berdasarkan tempat penemuannya, maka alat tersebut diragukan sebagai peninggalan. Pithecanthropus Soloensis (H.R. Van Heekeren 1972: 58-59).

Di samping temuan-temuan tersebut di atas, menurut keterangan Drs. Goenadi Nitihaminoto masih ada temuan alat-alat tulang lain yang merupakan hasil ekskavasi-ekskavasi yang dilaksanakan sejak tahun 1976 sampai dengan 1979. Hasil-hasil penelitian ini belum termasuk dalam tulisan ini, mengingat sampai sekarang masih dalam tahap analisis.

\section{B. Hasil Penelitian Tahun 1980}

Penelitian yang dilakukan pada tahun 1980 oleh Proyek Penelitian Purbakala Yogyakarta bekerja sama dengan Unit Paleoanthropologi Fakultas Kedokteran UGM, berhasil menemukan empat buah alat tulang di samping sejumlah besar fosil-fosil tulạng binatang dan enam buah bola batu (Truman Simanjuntak 1980).

Keempat alat tulang tersebut adalah sebagai berikut:

Alat tulang 1 : Bentuk seperti pisau dengan salah satu sisinya tajam. Salah satu ujungnya runcing sedang ujung lainnya tumpul dan tebal: Permukàan salah satu sisinya (sisi luar tulang) halus dan aus yang kelihatannya disebabkan pemakaian. Sisi lainnya (sisi dalam tulang) tidak sehalus sisi luarnya, tetapi keausan juga terdapat di permukáan nya.

Permukaan yang halus dan aus tersebut semakin jelas terlihat ke arah bagian tajaman. Panjang alat ini $8,5 \mathrm{~cm}$, lebar max. 2,5 cm dan lebar pangkal 1,5 $\mathrm{cm}$ (gambar 1). 
Temuan assosiasi berupa fragmen-fragmen tulang binatang.

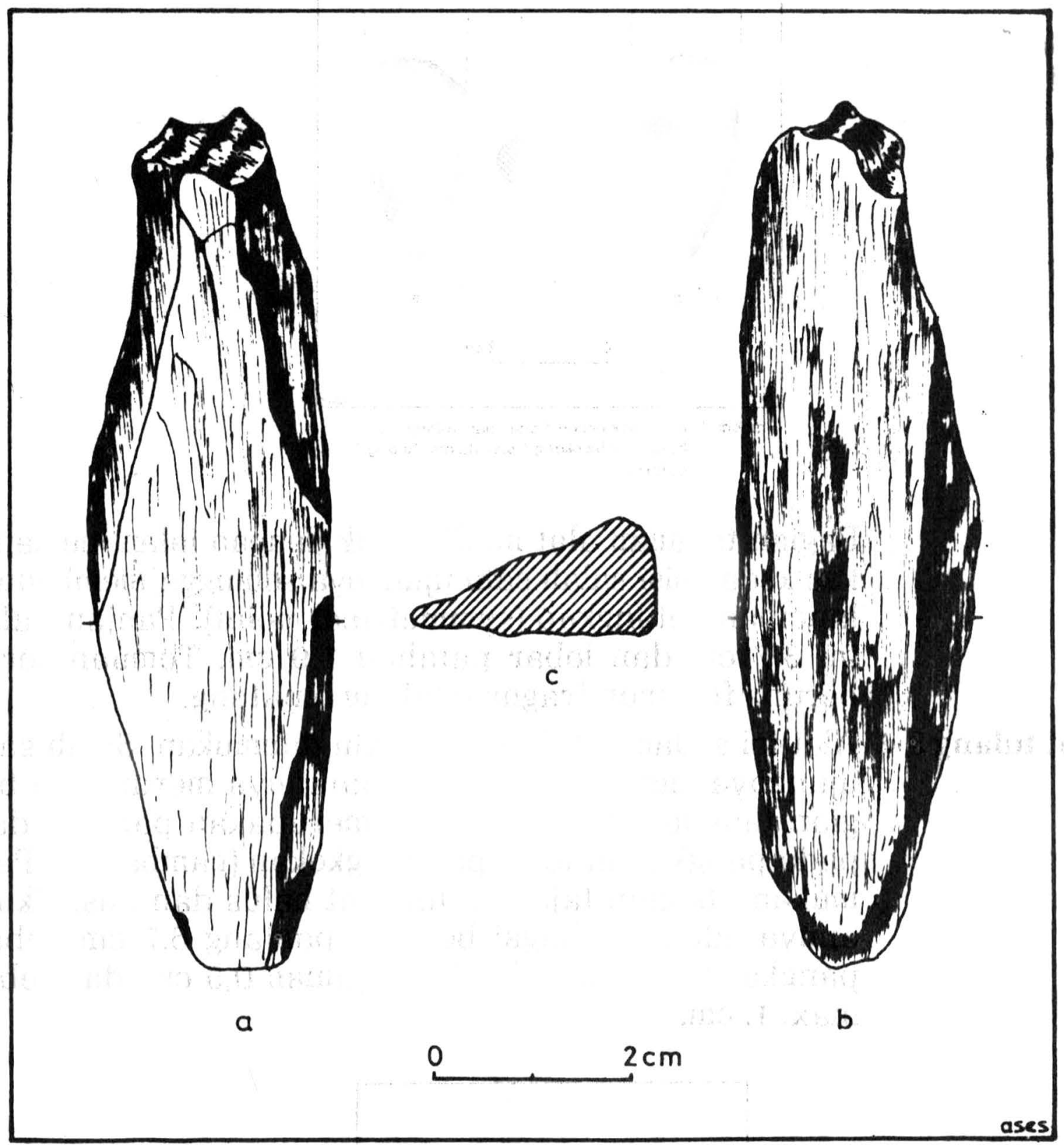

Gambar 1. a. Tampak depan ( sisi luar tulang).

b. Tampak belakang ( sisi dalam tulang).

c. Irisan.

Alat tulang 2 : Alat ini tampaknya sudah patah seperti terlihat pada salah satu ujungnya yang tidak rata (gambar: 2). Ujung lainnya runcing dan merupakan bagian tajaman. Pada salah satu sisinya terlihat bekas-bekas pemakaian berupa permukaan yang halus dan aus dan hal ini terlihat jelas mulai dari sekitar pertengahan fragmen hingga bagian tajaman.

Sisi lainnya yaitu sisi dalam tulang agak kasar. 


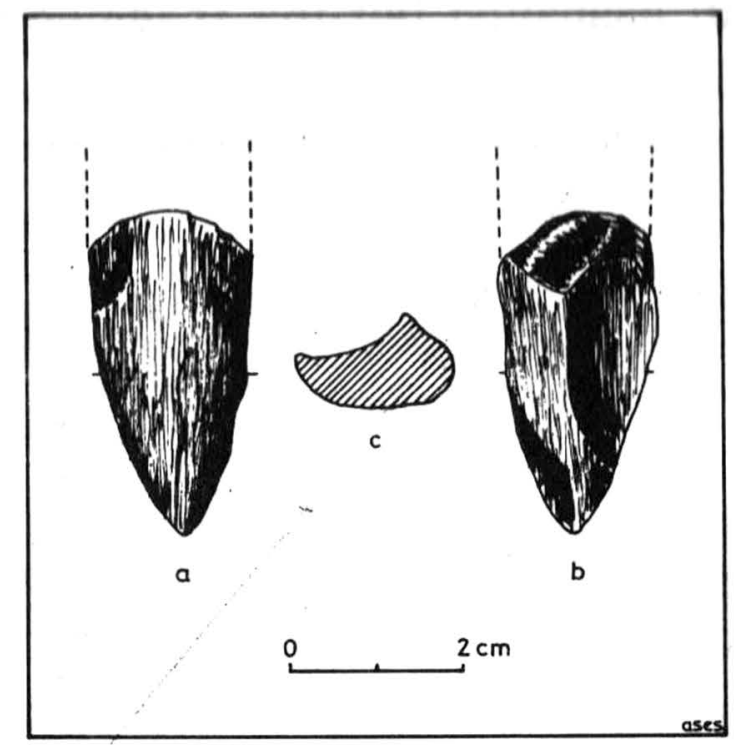

Gambar 2. a.Tampak depan ( sisi luar tulang ).

b. Tampak belakang ( sisi dalam tulang ).

c. Irisan

Bagian tajaman alat ini dibentuk dengan jalan memangkas kedua sisi salah satu ujungnya sehingga membentuk lancipan setangkup (symmetrical point). Panjang alat ini $3,7 \mathrm{~cm}$ dan lebar patahan $1,9 \mathrm{~cm}$. Temuan serta berupa fragmen-fragmen tulang binatang.

Alat tulang 3 : Alat ini sudah patah pada waktu ditemukan. Salah satu ujungnya meruncing dan kelihatannya merupakan bagian tajaman. Ujung lainnya merupakan pangkal dan pada pangkal ini terdapat bengkokan (gambar: 3). Permukaan bagian tajaman terlihat halus dan aus. Ukurannya adalah sebagai berikut: panjang 6,7 cm, lebar pangkal $1 \mathrm{~cm}$, lebar bagian tajaman $0,5 \mathrm{~cm}$, dan tebal $\max .1 . \mathrm{cm}$.

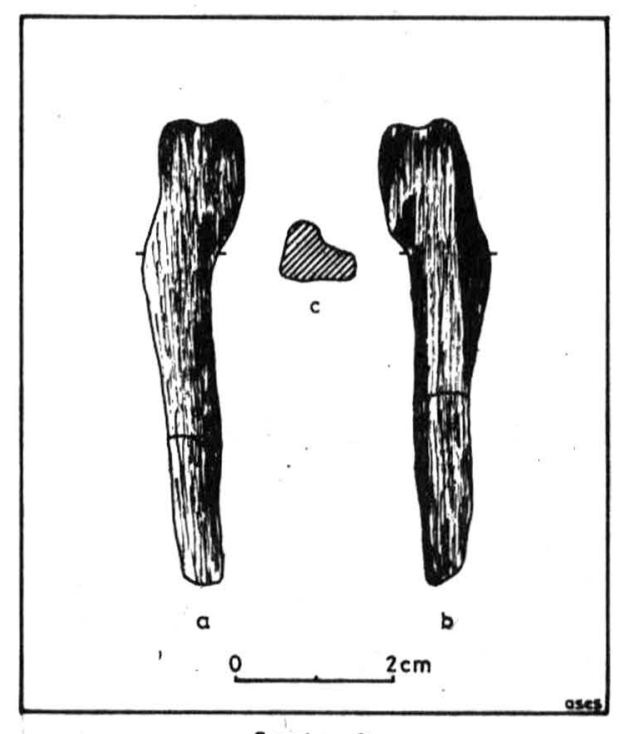

a. Tampak depan ( sisi luar tulang).

b. Tampak belakang ( sisi dalam tulang)

c. Irisan. 


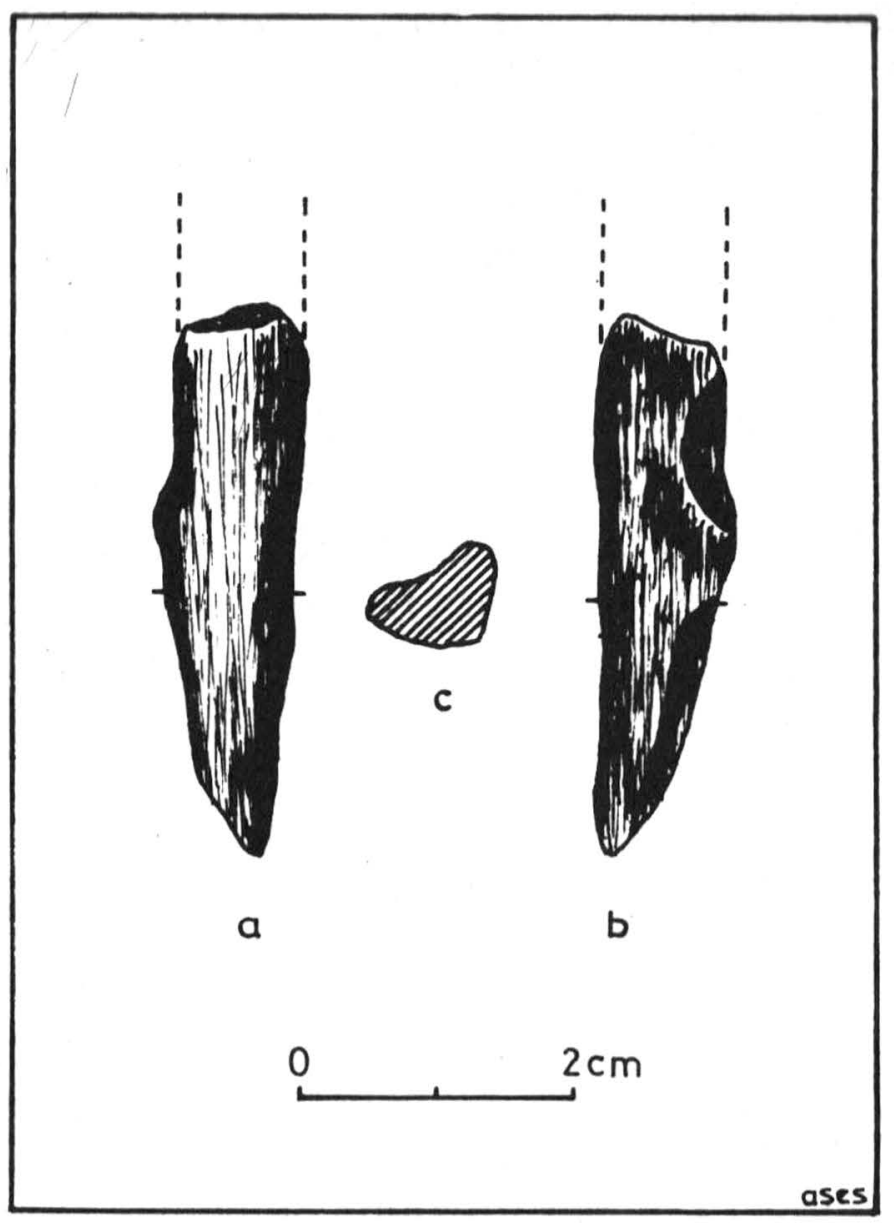

Gambar 4.
a. Tampak depan ( sisi luar tulang ).
b. Tampak belakang ( sisi dalam tulang ) .
c. Irisan.

Alat tulang 4 : Seperti halnya alat tulang 2 di atas, alat ini kelihatannya sudah patah pada bagian pangkalnya. Bagian tajaman dibentuk dengan membuat lancipan pada salah satu ujungnya dan pembentukannya dilakukan dengan jalan memangkas salah satu sisi. Pada bagian tajaman terlihat bekas-bekas pemakaian berupa permukaan yang halus dan aus. Alat ini menunjukkan tingkat fosilisasi yang lebih sempurna dibanding fragmen-fragmen tulang lainnya. Warnanya hitam pekat. Temuan serta adalah berupa fragmen-fragmen tulang binatang. Ukuran selengkapnya sebagai serikut: panjang $3,8 \mathrm{~cm}$, lebar pangkal 0,9 cm dan tebal nax. 0,7 cm. (gambar 4).

\section{III}

\section{PENUTUP}

Penemuan alat-alat tulang di atas memberikan suatu gambaran tentang perkembangan teknologi masyarakat pendukungnya. Tulang- 
tulang dan tanduk binatang hasil buruan serta duri ikan dimanfaatkan untuk dijadikan alat dalam memenuhi kebutuhannya.

Alat tanduk yang ditemukan berasal dari tanduk rusa, selama ini belum ditemukan alat dari tanduk binatang lain. Melihat ujung-ujungnye yang runcing tampaknya digunakan sebagai alat pencungkil atau mungkin juga sebagai belati (R.P. Soejono dkk., 1975: 107). Alat duri ikan yang ditemukan umumnya berwujud mata tombak.

Alat-alat dari tulang di samping sebagai mata tombak, sebagian lainnya lebih tepat digolongkan sebagai alat lancipan. (point tools). Alat-alat lancipan ini dibuat dengan jalan memecan tulang panjang binatang dan pecahan-pecahan tersebut dikerjakan lebih lanjut dengan jalan meruncingkan salah satu ujungnya. Peruncingan bisa terjadi hanya pada salah satu sisi dan bisa pula pada kedua sisi tulang. Perundingan yang hanya pada salah satu sisi akan menghasilkan lancipan yang lidak setangkup (asymmetrical point), sedang peruncingan yang terjadi pada ke dua sisi akan menghasilkan lancipan setangkup (symmetrical point).

Melihat tempat penemuannya yang satu konteks dengan temuan Pithecanthropus Soloensis, diduga alat-alat tulang ini merupakan hasil teknologi dari Pithecanthropus Soloensis. Tetapi lain halnya dengan temuan mata tombak dari Sidorejo tersebut di atas, alat ini diragukan sebagai hasil teknologi Pithecanthropus Soloensis mengingat lokasinya di ulas lempat penemuan fosil-fosil. (H.R. Van Heekeren 1972: 58-59).

Ponelitian terhadap alat-alat tulang Ngandong sangat diperlukan lebih lunjut mengingat pentingnya alat ini dalam menggambarkan salah satu loknologi yang berkembang pada waktu itu.

\section{Kepustakaan}

Heckeren H.R. Van, The Stone age of Indonesia, The Hague: Martinus (1972) Nijhoff.

Jacob, T.,"New finds of lower and middle Pleistocene hominines from

(1978a) Indonesia and an examination of their antiquity" dalam Fumiko Ikawa - Smith (ed). Early Palaeolithic in South and East Asia, pp. 13-22, Mouton Publisher: The Hague.

(1978b) ', The Puzzle of Solo man', Modern Quartenary research in Southeast Asia, 4, 31-40.

Oakley, Kenneth P., Man the tool maker, The University of Chicago (1972) Press.

Soejono R.P, dkk., Sejarah Nasional Indonesia I, Jakarta: Departemen (1975) P dan K.

The Encyclopedia Americana, 18, International Edition.

(1978)

Truman Simanjuntak, Laporan arkeologi penelitian Paleoanthropologi

(1980) Ngandong, (belum diterbitkan). 